\title{
Radium 223 dichloride for prostate cancer treatment
}

This article was published in the following Dove Press journal:

Drug Design, Development and Therapy

6 September 2017

Number of times this article has been viewed

\section{Emmanuel Deshayes ${ }^{1,2}$ \\ Mathieu Roumiguie ${ }^{3}$ \\ Constance Thibault ${ }^{4}$ \\ Philippe Beuzeboc ${ }^{5}$ \\ Florent Cachin ${ }^{6}$ \\ Christophe Hennequin ${ }^{7}$ \\ Damien Huglo ${ }^{8}$ \\ François Rozet ${ }^{9}$ \\ Diana Kassab-Chahmi ${ }^{10}$ \\ Xavier Rebillard"I \\ Nadine Houédél,12}

'Radiobiology Unit, INSERM UI I94, Institut du Cancer de Montpellier (ICM), ${ }^{2}$ Department of Nuclear Medicine, Institut du Cancer de Montpellier (ICM), Montpellier, ${ }^{3}$ Urology Department, Andrology and Renal Transplantation, $\mathrm{CHU}$

Rangueil, Toulouse, ${ }^{4}$ Medical Oncology Department, Hôpital Européen Georges Pompidou, ${ }^{5}$ Oncology Department, Institut Curie, ${ }^{6}$ Department of Nuclear Medicine, $\mathrm{CHU}$, Clermont-Ferrand,

${ }^{7}$ Radiotherapy Department, Hôpital Saint Louis, Paris, ${ }^{8}$ Department of Nuclear Medicine, CHRU, Lille, 'Urology Department, Institut Mutualiste Montsouris, ${ }^{10}$ Intergroupe coopérateur francophone de recherche en onco-urologie, Paris, "Urology Department, Clinique BeauSoleil, Montpellier, ${ }^{12}$ Medical Oncology Department, Institut de Cancérologie du Gard - CHU Caremeau, Nîmes, France
Correspondence: Nadine Houédé Medical Oncology Department, Institut de Cancérologie du Gard - CHU Caremeau, Nîmes, France Email nadine.houede@chu-nimes.fr

\begin{abstract}
Prostate cancer is the most common malignant disease in men. Several therapeutic agents have been approved during the last 10 years. Among them, radium-223 dichloride $\left(\right.$ Xofigo $^{\circledR}$ ) is a radioactive isotope that induces irreversible DNA double-strand breaks and consequently tumor cell death. Radium-223 dichloride is a calcium-mimetic agent that specifically targets bone lesions. Radium-223 dichloride has been approved for the treatment of metastatic castration-resistant prostate cancer with symptomatic bone metastases, without known visceral metastases. In this review, first we summarize the interplay between prostate tumor cells and bone microenvironment; then, we discuss radium-223 dichloride mechanism of action and present the results of the available clinical trials and future developments for this new drug.
\end{abstract}

Keywords: bone metastasis, mCRPC, mechanism, drug, agents, development

\section{Introduction}

Prostate cancer represents the second most frequent cancer worldwide, with an incidence of 1.09 million patients in $2012 .{ }^{1}$ Although most patients are cured by local treatment, 20\%-30\% will have a recurrence, especially in bone. Bone metastases often lead to pain or skeletal events (fracture, spinal cord compression) and, therefore, may decrease the patients' quality of life. Radium-223 $\left({ }^{223} \mathrm{Ra}\right.$; Xofigo $\left.{ }^{\circledR}\right)$ is an $\alpha$-emitting radionuclide that, like calcium, is incorporated in the bone matrix at sites of active mineralization via osteoblasts. Therefore, it specifically targets bone metastases. In the Phase III trial ALSYMPCA, ${ }^{223}$ Ra showed an overall survival (OS) benefit in patients with castration-resistant prostate cancer (CRPC) and symptomatic bone metastases. ${ }^{2}$ This led to its approval by the US Food and Drug Administration in 2013. This review, which is the result of a multidisciplinary collaboration by the Intergroupe Coopérateur Francophone de recherche en onco-urologie (ICFuro), discusses the place of ${ }^{223} \mathrm{Ra}$ in the therapeutic landscape of prostate cancer. It will first describe the mechanism of action of this new agent against bone metastases. It will then summarize the available clinical data and the place of ${ }^{223} \mathrm{Ra}$ in the current clinical practice. Finally, it will give information on the ongoing trials that assess ${ }^{223} \mathrm{Ra}$ for prostate cancer management.

\section{Treatment options for metastatic CRPC}

Besides ${ }^{223} \mathrm{Ra}$, several other agents have shown efficacy in metastatic CRPC (mCRPC). Since 2004, five drugs have been approved for mCRPC treatment, leading to an improvement of progression-free survival and OS. First, docetaxel, a microtubule poison from the taxane family, was approved on the basis of a 2.5-month survival improvement ( 16.4 vs 18.9 months; $P=0.009$ ) compared with mitoxantrone (standard treatment). ${ }^{3,4}$ Then, in 2010, the results of the TROPIC study in a post-docetaxel setting 
(OS increase of 2.4 months compared with mitoxantrone; 12.7 vs 15.1 months; $P=0.0001$ ) led to the approval of cabazitaxel, a taxane with lower affinity for drug efflux pumps compared with previous molecules of the same class. $^{5}$ The same year, it was shown that sipuleucel-T, an autologous cellular immunotherapy, prolongs survival in chemotherapy-naive patients with asymptomatic or minimally symptomatic mCRPC compared with controls (25.8 months in the sipuleucel-T group vs 21.7 months in the placebo group). ${ }^{6}$ The last two drugs are "second generation" hormonal treatments that target the androgen receptor signaling pathway. The first one is abiraterone acetate (AA) that targets CYP17A1, a key enzyme involved in androgen synthesis. Its approval relied on a 4-month OS improvement in patients with bone metastatic prostate cancer after docetaxel treatment compared with placebo (15.8 months vs 11.2 months; $P<0.0001)$ and also in chemotherapy-naive patients (34.7 vs 30.3 months; $P=0.0033$ ). ${ }^{7,8}$ The second one is enzalutamide, an androgen receptor antagonist. When used as first-line treatment of patients with $\mathrm{mCRPC}$ and bone or visceral metastases, enzalutamide improved OS by 2 months compared with placebo (32.4 vs 30.2 months; $P<0.001){ }^{9}$ Similar results were obtained also in a post-docetaxel setting (OS from 13.6 months to 18.4 months; $P<0.001$ ). ${ }^{10}$ However, despite the introduction of these new molecules for mCRPC clinical management, the right sequence for systemic therapies in advanced prostate cancer is not clearly defined. ${ }^{11}$ Although most patients receive second-generation hormonal treatments first, emerging evidence indicates that the most critical issue for patients is to receive at least three different lines of treatment. ${ }^{12}$

\section{Bone metastasis formation}

Prostate cancer cells (PCs) have an important tropism for the bone matrix. Experimental studies in animal models showed the role of the primary tumor in preparing the bone matrix for metastasis development. ${ }^{13,14}$ By increasing the activity of growth factors (such as vascular endothelial growth factor-A and placental growth factor), PCs activate bone marrow mesenchymal cells and progenitor endothelial cells to promote the development of a PC host structure with vascularization. Specifically, growth factors create an extracellular matrix prone to receive PCs. Then, osteoblasts, PCs, and other cells in the bone microenvironment secrete a range of additional molecules, such as growth factors (insulin-like growth factor, fibroblast growth factor, transforming growth factor- $\beta$ ), chemokines (CXCL-12, CCL22, and so on) and cytokines (RANKL), that can anchor PCs to the bone matrix. ${ }^{15,16}$
Furthermore, Morris and Edwards reported the potential contribution of both white adipose tissue and bone marrow adipocytes in triggering PC migration and in supporting tumor growth and metastasis formation. ${ }^{17}$ Once installed, PCs can affect the bone homeostasis between bone matrix resorption and formation. In most cases, the nature of bone metastases in prostate cancer is osteoblastic. Indeed, histopathological analysis of PC bone metastases demonstrated the presence of a large number of osteoblasts adjacent to PCs, in contrast to normal bone or bone metastases from other cancers. ${ }^{18}$ The interaction between the bone microenvironment and PCs creates a vicious circle that favors osteoblastic bone metastases. ${ }^{19}$ Indeed, through local and systemic factors, PCs lead to the activation of osteoblast cells. In turn, osteoblasts control bone matrix resorption by activating (through the cytokine RANKL) or inhibiting (through osteoprotegerin) osteoclasts. At the beginning of bone metastasis formation, tumor-derived factors and RANKL-secreting osteoblasts can both activate osteoclasts, leading to bone resorption that subsequently creates more space for the dominant osteoblastic lesions. Thus, cytokines and growth factors released during bone resorption can foster this vicious cycle by facilitating the sustained proliferation of PCs and osteoblasts. Moreover, an increase in serum osteoprotegerin level is also observed in patients with advanced prostate cancer. These findings led Ibrahim et al to propose that osteoblasts play a predominant role in prostate cancer progression in bone through their ability to control PC and osteoclast proliferation. ${ }^{16}$

In conclusion, in prostate cancer, bone metastases result from complex interactions between PCs, bone tissue, and bone microenvironment that are regulated by many local and systemic growth factors.

\section{${ }^{223} \mathrm{Ra}$ mechanism of action}

${ }^{223} \mathrm{Ra}$ is a radioactive isotope that decays to stable lead $\left({ }^{207} \mathrm{~Pb}\right)$ after a complex disintegration path with several radioactive daughters that produce four alpha particles (Figure 1). ${ }^{223} \mathrm{Ra}$ decay chain is as follows: ${ }^{223} \mathrm{Ra}\left(\mathrm{T}_{1 / 2}=11.4\right.$ days, $\left.\alpha\right) \rightarrow{ }^{219} \mathrm{Rn}$ $\left(\mathrm{T}_{1 / 2}=3.96\right.$ seconds, $\left.\alpha\right) \rightarrow{ }^{215} \mathrm{Po}\left(\mathrm{T}_{1 / 2}=1.78\right.$ milliseconds, $\left.\alpha\right) \rightarrow$ ${ }^{211} \mathrm{~Pb}\left(\mathrm{~T}_{1 / 2}=36.1\right.$ minutes, $\left.\beta-\right) \rightarrow{ }^{211} \mathrm{Bi}\left(\mathrm{T}_{1 / 2}=2.15\right.$ minutes, $\left.\alpha\right) \rightarrow$ ${ }^{207} \mathrm{Tl}\left(\mathrm{T}_{1 / 2}=4.77\right.$ minutes, $\left.\beta-\right) \rightarrow{ }^{207} \mathrm{~Pb}$ (stable). ${ }^{223} \mathrm{Ra}$ can be produced quite easily and in high amount from elution of an actinium-227/thorium-227 generator system (actinium-227 is produced by neutron irradiation of natural radium-226). ${ }^{223} \mathrm{Ra}$ physical half-life of 11.4 days allows long-distance shipment. ${ }^{20,21}$ The average particle energy per decay of ${ }^{223} \mathrm{Ra}$ is $5.7 \mathrm{MeV}$. The combined energy for the complete decay chain of ${ }^{223} \mathrm{Ra}$ including daughter radionuclides is $28.2 \mathrm{MeV} \cdot{ }^{22}$ 


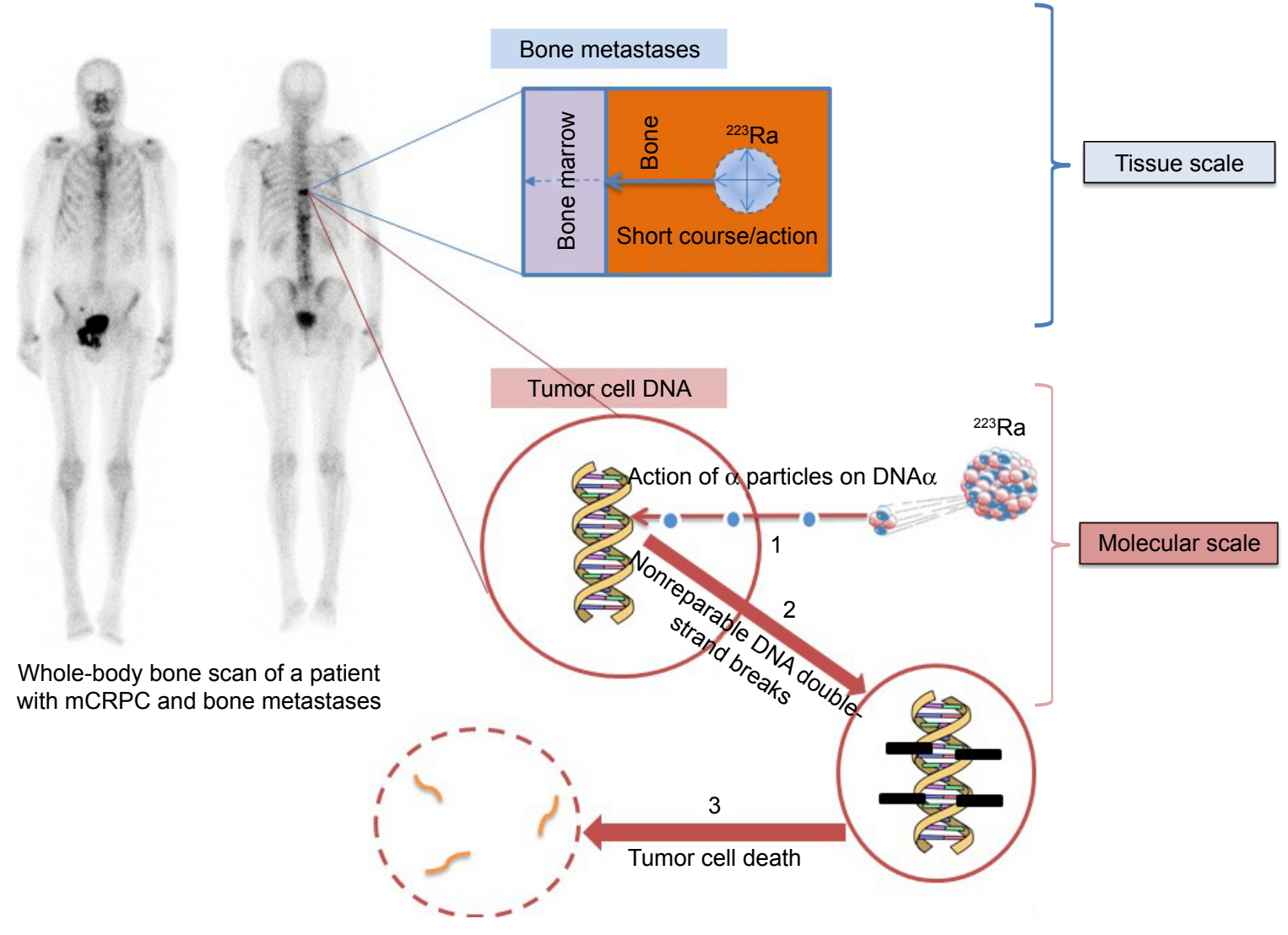

Figure $\mathbf{I}{ }^{223}$ Ra mechanism of action in bone metastases.

Abbreviations: ${ }^{233} \mathrm{Ra}$, radium-223; mCRPC, metastatic castration-resistant prostate cancer.

This is much higher than that of beta-emitter bone-targeting radiopharmaceuticals, such as ${ }^{89} \mathrm{SrCl}_{2}$ and ${ }^{153} \mathrm{Sm}$-EDTMP, with, respectively, 0.58 and $0.22 \mathrm{MeV} .{ }^{23}$ Gamma particles are also emitted during ${ }^{223} \mathrm{Ra}$ disintegration, allowing scintigraphy imaging (eg, for dosimetric studies). After intravenous injection, ${ }^{223} \mathrm{Ra}$ acts as a calcium analog and about $25 \%$ is taken up by bone. It concentrates in sites of active mineralization with high osteoblastic activity (well visualized on bone scans). ${ }^{24}{ }^{223} \mathrm{Ra}$ is mainly excreted by the gastrointestinal tract, and $<1 \%$ of the injected activity remains in the blood 24 hours after injection. ${ }^{25}$ Bone endosteum is the organ with the highest dose (16 Gy) after ${ }^{223} \mathrm{Ra}$ injection at therapeutic dose (six intravenous injections of $50 \mathrm{kBq} / \mathrm{kg}{ }^{223} \mathrm{Ra}$ chloride for a $70 \mathrm{~kg}$ patient), and the corresponding absorbed dose to the red bone marrow is $1.6 \mathrm{~Gy} .{ }^{24}$ No significant redistribution of ${ }^{223} \mathrm{Ra}$ radioactive daughters has been observed in preclinical ${ }^{22}$ and clinical studies. ${ }^{26}$

${ }^{223} \mathrm{Ra}$ radiobiological effects are mainly based on the direct damage of tumor cell DNA (nonreparable DNA double-strand breaks, leading to tumor cell death) ${ }^{27}$ by alpha particles. Thanks to their high linear energy transfer (LET) $(80 \mathrm{keV} / \mu \mathrm{m})$ and a very short range $(<100$ micrometers $)$, alpha particles produce a dense ionization around the disintegration site..$^{23}$ The high LET leads to cytotoxic effects that are independent of the oxygen concentration; this is particularly interesting in bone (and bone metastases) because it is a quite hypoxic organ.

\section{Clinical results}

Different from cytotoxic chemotherapy, ${ }^{223} \mathrm{Ra}$ dose is not determined based on the patient's body surface area but on his weight, as reported by a Phase II, randomized, doubleblind study that compared three ${ }^{223} \mathrm{Ra}$ doses $(25,50$, and $80 \mathrm{kBq} / \mathrm{kg}$ ) administered every 6 weeks for a total of six injections at most. ${ }^{28}$ Of note, because of its mechanism of action, ${ }^{223} \mathrm{Ra}$ biological response is better evaluated by assessing the decrease of alkaline phosphatase (ALP) than prostatespecific antigen (PSA) level. Although the study observed a dose-response relationship, the biological benefit on ALP was not significantly different in the 50 and $80 \mathrm{kBq} / \mathrm{kg}$ dose groups. Therefore, the regimen chosen for the Phase III trial was $50 \mathrm{kBq} / \mathrm{kg}$ every 6 weeks.

The ALSYMPCA randomized Phase III trial compared ${ }^{223} \mathrm{Ra}$ efficacy versus placebo in 921 patients with CRPC and 
symptomatic bone metastases. ${ }^{29}$ This study included only patients with disease progression after or during docetaxel treatment (the only available agent at the time of the trial that showed some OS benefit in MCRPC), or unfit to receive chemotherapy (43\% of the enrolled men). Conversely, it excluded patients with visceral metastases. Analysis of the results showed an OS benefit (primary endpoint of the study) in patients treated with ${ }^{223} \mathrm{Ra}$ compared with patients who received placebo (14.9 months vs 11.3 months, $\mathrm{HR}=0.7$ [95\% CI 0.58-0.83]; $P<0.001$ ). Patients treated with ${ }^{223} \mathrm{Ra}$ also had a longer time to symptomatic skeletal events (15.6 months vs 9.8 months, HR =0.66 [95\% CI 0.52-0.83]; $P=0.00037$ ) and a better biological response (Table 1). The treatment was well tolerated. The rate of grade 3/4 adverse events was not statistically different between groups. More than half of the patients $(58 \%)$ received the six planned injections. ${ }^{223} \mathrm{Ra}$ main toxicities were anemia and thrombocytopenia and diarrhea (Table 2). The predictive factors associated with $\mathrm{G} 2 / 4$ hematological toxicities were the number of bone metastases $(6-20$ vs $<6$, odds ratio
$[\mathrm{OR}]=2.76 ; P=0.022)$ and PSA concentration $(\mathrm{OR}=1.65$; $P=0.006)$ for anemia; preuse or not of docetaxel $(\mathrm{OR}=2.16$; $P=0.035)$ and baseline hemoglobin and platelet decrease $(\mathrm{OR}=1.35 ; P=0.008 \text { and } \mathrm{OR}=1.44 ; P=0.030 \text {, respectively })^{30}$ for thrombocytopenia. The number of ${ }^{223} \mathrm{Ra}$ injections was not associated with higher risk of adverse events. The quality of life during treatment was evaluated with two self-report questionnaires (EuroQol-5D and FACT-P v4) and was better in patients treated with ${ }^{223} \mathrm{Ra}$ than in controls. ${ }^{31}$

The ALSYMPCA study main limitation was the absence of patients previously or concomitantly treated with new hormonal therapies (NHT), such as abiraterone or enzalutamide, that are now widely used for MCRPC management. A subsequent single-arm Phase III-b trial, conducted to enable early access to ${ }^{223} \mathrm{Ra}$ before regulatory approval, included patients concomitantly treated with NHT. ${ }^{32}$ Moreover, $60 \%$ of patients had previously received docetaxel, $40 \% \mathrm{AA}$, and $8 \%$ enzalutamide. Patients $(n=696)$ received one ${ }^{223} \mathrm{Ra}$ dose ( 50 or $55 \mathrm{kBq} / \mathrm{kg}$ ) every 4 weeks (one to six injections in total). During the trial, ${ }^{223} \mathrm{Ra}$ was associated with NHT in

Table I ${ }^{223} \mathrm{Ra}$ efficacy in metastatic castration-resistant prostate cancer

\begin{tabular}{|c|c|c|c|c|c|c|}
\hline Trial type & Design & Population & $\begin{array}{l}\text { Previous treatment } \\
\text { (\% of patients) }\end{array}$ & PSA response & ALP response & os \\
\hline $\begin{array}{l}\text { Phase } \|^{35} \\
N=100\end{array}$ & $\begin{array}{l}\text { Four arms: } 5 \mathrm{kBq} / \mathrm{kg} \\
25 \mathrm{kBq} / \mathrm{kg} / 6 \mathrm{w} \\
50 \mathrm{kBq} / \mathrm{kg} / 6 \mathrm{w} \\
100 \mathrm{kBq} / \mathrm{kg} / 6 \mathrm{w} \\
\text { (single injection) }\end{array}$ & $\begin{array}{l}\text { mCRPC with } \\
\text { symptomatic bone } \\
\text { metastases }\end{array}$ & $\begin{array}{l}\text { Docetaxel (36) } \\
\text { Bicalutamide (63) } \\
\text { Estramustine (17) }\end{array}$ & NR & NR & NR \\
\hline $\begin{array}{l}\text { Phase } \|^{28} \\
N=122\end{array}$ & $\begin{array}{l}\text { Three arms: } \\
25 \mathrm{kBq} / \mathrm{kg} / 6 \mathrm{w} \\
50 \mathrm{kBq} / \mathrm{kg} / 6 \mathrm{w} \\
80 \mathrm{kBq} / \mathrm{kg} / 6 \mathrm{w} \\
\text { (up to six injections) }\end{array}$ & $\begin{array}{l}\text { mCRPC with bone } \\
\text { metastases }\end{array}$ & $\begin{array}{l}\text { Docetaxel }(20) \\
\text { Anti-androgens }(>92)\end{array}$ & $\begin{array}{l}\text { Decrease }>30 \% \text { at } \\
24 \mathrm{w}: 16 \%\end{array}$ & $\begin{array}{l}\text { Decrease }>50 \% \text { at } \\
24 \text { w: } 50 \%\end{array}$ & NR \\
\hline $\begin{array}{l}\text { Phase } 1 I^{29} \\
\mathrm{~N}=921\end{array}$ & $\begin{array}{l}\text { Placebo vs } 50 \mathrm{kBq} / \\
\mathrm{kg} / 6 \mathrm{w}^{223} \mathrm{Ra} \text { (up to } \\
\text { six injections) }\end{array}$ & $\begin{array}{l}\text { mCRPC with } \\
\text { symptomatic bone } \\
\text { metastases, without } \\
\text { visceral metastases }\end{array}$ & Docetaxel (57) & $\begin{array}{l}\text { Decrease }>30 \% \text { at } \\
\text { I2 w: } 16 \% \text { vs } 6 \% \text {, } \\
P<0.00 \text { I } \\
\text { Median time to } \\
\text { PSA progression: } \\
\text { HR }=0.64 ; 95 \% \mathrm{Cl} \\
0.54-0.77 ; P<0.00 \text { I }\end{array}$ & $\begin{array}{l}\text { Decrease }>30 \% \\
\text { at } 4 \text { w: } 47 \% \text { vs } 3 \% \text {, } \\
P<0.00 \text { I } \\
\text { Median time to } \\
\text { ALP progression: } \\
\text { HR }=0.17 ; 95 \% \mathrm{Cl} \\
0.13-0.22 ; P<0.00 \text { I }\end{array}$ & $\begin{array}{l}\text { I } 4.9 \text { mo vs } \\
\text { I I } .6 \mathrm{mo} \mathrm{HR}=0.70 \text {; } \\
95 \% \mathrm{Cl} 0.58-0.83 \\
P<0.00 \text { I }\end{array}$ \\
\hline $\begin{array}{l}\text { Phase III-b } \\
N=696\end{array}$ & $\begin{array}{l}50 \text { or } 55 \mathrm{kBq} / \mathrm{kg} / 6 \mathrm{w} \\
{ }^{223} \mathrm{Ra} \text { (up to six } \\
\text { injections) } \\
27 \% \text { received } \\
\text { concomitantly } \mathrm{AA} / \text { Enza }\end{array}$ & $\begin{array}{l}\text { mCRPC with } \\
\text { asymptomatic or } \\
\text { symptomatic bone } \\
\text { metastases, without } \\
\text { visceral metastases }\end{array}$ & $\begin{array}{l}\text { Docetaxel (60) } \\
\text { AA (40) } \\
\text { Enza (8) }\end{array}$ & $\begin{array}{l}\text { Decrease }>30 \% \text { at } \\
12 \mathrm{w}: \\
14 \%\end{array}$ & $\begin{array}{l}\text { Decrease }>30 \%: \\
47 \%\end{array}$ & $16 \mathrm{mo}$ \\
\hline $\begin{array}{l}\text { Retrospective } \\
\text { study }{ }^{33} \mathrm{~N}=144\end{array}$ & ${ }^{223} \mathrm{Ra}$ up to six injections & $\begin{array}{l}\text { mCRPC with bone } \\
\text { metastases }\end{array}$ & $\begin{array}{l}\text { Chemotherapy (55) } \\
\text { AA and/or Enza ( } 46.5)\end{array}$ & $\begin{array}{l}\text { Decrease }>50 \% \\
\text { from baseline: } \\
14 \%(n=18 / \mid 28)\end{array}$ & $\begin{array}{l}\text { Decrease }>50 \% \\
\text { from baseline: } \\
23 \%(n=16 / 70)\end{array}$ & $15.7 \mathrm{mo}$ \\
\hline $\begin{array}{l}\text { Retrospective } \\
\text { study }^{33} \mathrm{~N}=58\end{array}$ & ${ }^{223} \mathrm{Ra}$ up to six injections & $\begin{array}{l}\text { mCRPC with bone } \\
\text { metastases }\end{array}$ & Docetaxel (52) & $\begin{array}{l}\text { Median PSA increase } \\
\text { from baseline: } \\
(225 \text { vs } 418)\end{array}$ & $\begin{array}{l}\text { Median ALP } \\
\text { decrease from } \\
\text { baseline: } \\
\text { (292 vs 138) }\end{array}$ & $8.33 \mathrm{mo}$ \\
\hline
\end{tabular}

Abbreviations: AA, abiraterone acetate; ALP, alkaline phosphatase; Enza, enzalutamide; mCRPC, metastatic castration-resistant prostate cancer; mo, months; NR, not reported; ${ }^{233} \mathrm{Ra}$, radium-223; OS, overall survival; PSA, prostate-specific antigen; w, weeks. 
Table $2{ }^{223} \mathrm{Ra}$ toxicity in patients with metastatic castration-resistant prostate cancer

\begin{tabular}{|c|c|c|c|c|c|}
\hline $\begin{array}{l}\text { Toxicities } \\
\text { (grade 3/4) }\end{array}$ & $\begin{array}{l}\text { Phase II } \\
\text { study }^{35} n=100\end{array}$ & $\begin{array}{l}\text { Phase II } \\
\text { study }^{28} n=\mid 22\end{array}$ & $\begin{array}{l}\text { Phase III } \\
\text { study }{ }^{29} \mathrm{n}=92 \text { I } \\
{ }^{223} \text { Ra vs placebo }\end{array}$ & $\begin{array}{l}\text { Phase III-b } \\
\text { study }\end{array}$ & $\begin{array}{l}\text { Retrospective } \\
\text { study }^{33}\end{array}$ \\
\hline \multicolumn{6}{|l|}{ Hematological } \\
\hline Anemia & $8 \%$ & $7 \%$ & $13 \%$ vs $13 \%$ & $12 \%$ & $5 \%$ \\
\hline Thrombocytopenia & $6 \%$ & $2 \%$ & $12 \%$ vs $6 \%$ & $3 \%$ & $5 \%$ \\
\hline Neutropenia & $3 \%$ & $<1 \%$ & $3 \%$ vs $1 \%$ & $2 \%$ & $4 \%$ \\
\hline \multicolumn{6}{|l|}{ Gastrointestinal } \\
\hline Diarrhea & NR & 0 & $25 \%$ vs $15 \%$ & $1 \%$ & NR \\
\hline Nausea & NR & 0 & $2 \%$ vs $2 \%$ & $<1 \%$ & NR \\
\hline
\end{tabular}

Abbreviations: ${ }^{233} \mathrm{Ra}$, radium-223; NR, not reported.

$27 \%$ of patients (AA in $20 \%$, enzalutamide in $5 \%$, and both in $2 \%$ ). Results are quite similar to those of the ALSYMPCA trial, with an OS of 16 months. The OS was longer in patients concomitantly treated with NHT compared with those without NHT and in docetaxel-naive patients who received also NHT compared with those pretreated with docetaxel. The biological response (PSA and ALP levels) at week 12 was consistent with the ALSYMPCA results. Specifically, PSA and ALP decreased by $>30 \%$ in $14 \%$ and $47 \%$ of patients, respectively (Table 1). Toxicities were less frequent than in the ALSYMPCA study, but this could be explained by the shorter follow-up. Nevertheless, $75 \%$ of patients experienced at least one treatment-related adverse event. The most frequent $\mathrm{G} 3 / 4$ toxicities were anemia (12\%), thrombocytopenia (3\%), back/bone pain $(3 \% / 4 \%)$, and spinal cord compression (3\%). The median number of ${ }^{223} \mathrm{Ra}$ injections was six and only $21 \%$ of patients discontinued the ${ }^{223} \mathrm{Ra}$ treatment because of adverse events. Since ${ }^{223} \mathrm{Ra}$ approval, several retrospective studies have reported the comparable efficacy and safety of this treatment in the clinic. ${ }^{33,34}$ The results of the published clinical trials on ${ }^{223} \mathrm{Ra}$ are summarized in Table $1{ }^{223} \mathrm{Ra}$ efficacy) and Table 2 ( ${ }^{223} \mathrm{Ra}$ toxicity profile).

Unfortunately, ${ }^{223} \mathrm{Ra}$ treatment for $\mathrm{MCRPC}$ is not reimbursed in all European countries, although its OS benefit has been demonstrated by the ALSYMPCA trial and robust data about ${ }^{223} \mathrm{Ra}$ efficacy and safety in combination with NHT have been reported. However, studies with high level of evidence on the optimal sequence of administration of all these treatments are lacking.

\section{Clinical management}

The decision to administer ${ }^{223} \mathrm{Ra}$ should be taken by a multidisciplinary committee that includes at least one oncologist and one nuclear medicine physician. As previously stated, this treatment may be proposed to patients with mCRPC and symptomatic bone metastases but no evidence of visceral metastases. Patients should have a medical consultation with the nuclear medicine physician before starting this treatment in order to check the indication and contraindications based on the clinical, biological, and bone scan data. Moreover, the physician should clearly explain to the patient the expected ${ }^{223} \mathrm{Ra}$ benefits (mainly on survival and pain relief) and potential side effects. The most relevant side effects reported in studies were related to quality of life ( $\mathrm{eg},{ }^{223} \mathrm{Ra}$ vs placebo: deterioration of Utility score: $36.0 \%$ vs $54.0 \% ; P<0.001$; $\mathrm{OR}=0.48 ; 95 \%$ CI $0.34-0.67$ or deterioration of FACT-P: $44.3 \%$ vs $51.6 \% ; P=0.095 ; \mathrm{OR}=0.75: 95 \%$ CI $0.53-1.05)^{31}$ or to medullar compression $(\mathrm{HR}=0.52 ; 95 \%$ CI $0.29-0.93$; $P=0.03) .{ }^{36}$ Some contraindications may be specifically investigated: jaw osteonecrosis, spinal cord compression, recent fractures, and inflammatory bowel disease (such as Crohn's disease and ulcerative colitis). Data about pain should be collected: pain localization and score (based on a visual analog pain scale), number and type of antalgic treatment. The bone metastasis osteoblastic activity must be confirmed by functional bone imaging (bone scan or sodium fluoride positron emission tomography/computed tomography). Before starting the ${ }^{223} \mathrm{Ra}$ treatment, patients need to have platelet count $\geq 100 * 10^{9} / \mathrm{L}$, hemoglobin level $\geq 10 \mathrm{~g} / \mathrm{dL}$, and absolute neutrophil count $\geq 1.5 * 10^{9} / \mathrm{L}$. Patients can undergo ${ }^{223} \mathrm{Ra}$ treatment and follow-up as outpatients because the estimated radiation dose to caregivers and household members is very low: $<2 \mu \mathrm{Sv} \mathrm{h}^{-1} \mathrm{MBq}^{-1}$ on contact and $0.02 \mu \mathrm{Sv} \mathrm{h}^{-1}$ $\mathrm{MBq}^{-1}$ at $1 \mathrm{~m}$ immediately after administration. ${ }^{37}$ Nuclear medicine services dispensing ${ }^{223} \mathrm{Ra}$ treatments must comply with the national regulations on radioactive materials. This is the first alpha emitter approved for routine clinical treatment, and health professionals working in nuclear medicine departments (nuclear medicine physicians, physicists, radiopharmacists, and technologists) must be specifically trained. Activity meters must be calibrated with a standard source before treatment initiation. Staff exposure is low, but ${ }^{223} \mathrm{Ra}$ has to be manipulated carefully with gloves and masks. The main potential issue is internal exposure (ie, accidental 
${ }^{223} \mathrm{Ra}$ intake by ingestion and/or inhalation). There is no specific procedure for patients' care, except to wear gloves if in contact with fluids/feces $\left({ }^{223} \mathrm{Ra}\right.$ is mainly excreted with the feces). ${ }^{223} \mathrm{Ra}$ injected activity (usually below $8 \mathrm{MBq}$ ) is very low compared with standard nuclear medicine diagnostic procedures (500-1,000 MBq of technetium-99 $\mathrm{m}$ for a bone scan, for example). At the end of the administration, surface contamination should also be checked.

The therapeutic procedure consists in the slow intravenous injection of $55 \mathrm{kBq} / \mathrm{kg}{ }^{223} \mathrm{Ra}$ (about 1 minute), in the department of nuclear medicine, under medical supervision (one injection every 4 weeks for a total of six injections). To avoid the risk of extravasation, the intravenous peripheral blood catheter should be inserted in a large vein by experienced personnel. The ALSYMPCA study did not report any specific reaction at the injection site; however, in the case of ${ }^{223} \mathrm{Ra}$ extravasation a specific procedure ${ }^{38}$ and dermatological follow-up should be proposed. Recently, a possible case of cutaneous cancer was observed after ${ }^{223} \mathrm{Ra}$ extravasation. ${ }^{39}$ After the injection, the patient is monitored for a short time and then he can go home. He needs to follow good hygiene practices for at least 1 week after the injection, including flushing the toilet several times after use, but specific radiation safety precautions are usually not required (like sleeping arrangements or limited time contact with children). The decision to administer the next cycle is based on clinical and biological parameters (platelet count $\geq 50 * 10^{9} / \mathrm{L}$, absolute neutrophil count $\left.\geq 1 * 10^{9} / \mathrm{L}\right)$.

\section{${ }^{223} \mathrm{Ra}$ place in therapy}

Two studies reported a benefit of ${ }^{223} \mathrm{Ra}$ on both OS and quality of life in chemotherapy-naive patients with mCRPC and symptomatic bone metastases. ${ }^{2,31}$ Currently, there is no indication for ${ }^{223} \mathrm{Ra}$ in patients with visceral metastases. Similar results (improved OS, time to biological progression, time to bone progression, pain, and quality of life) were reported in patients with bone metastases and no known visceral metastasis who received docetaxel prior to ${ }^{223} \mathrm{Ra}$ administration. ${ }^{32}$ No published data are available on ${ }^{223} \mathrm{Ra}$ efficacy in consolidation settings following docetaxel treatment. In conclusion, ${ }^{223} \mathrm{Ra}$ is recommended only in the absence of visceral metastases.

Several ongoing trials (summarized in Table 3 and full list available at ClinicalTrials.gov) are validating ${ }^{223}$ Ra efficacy in

Table 3 Ongoing clinical trials

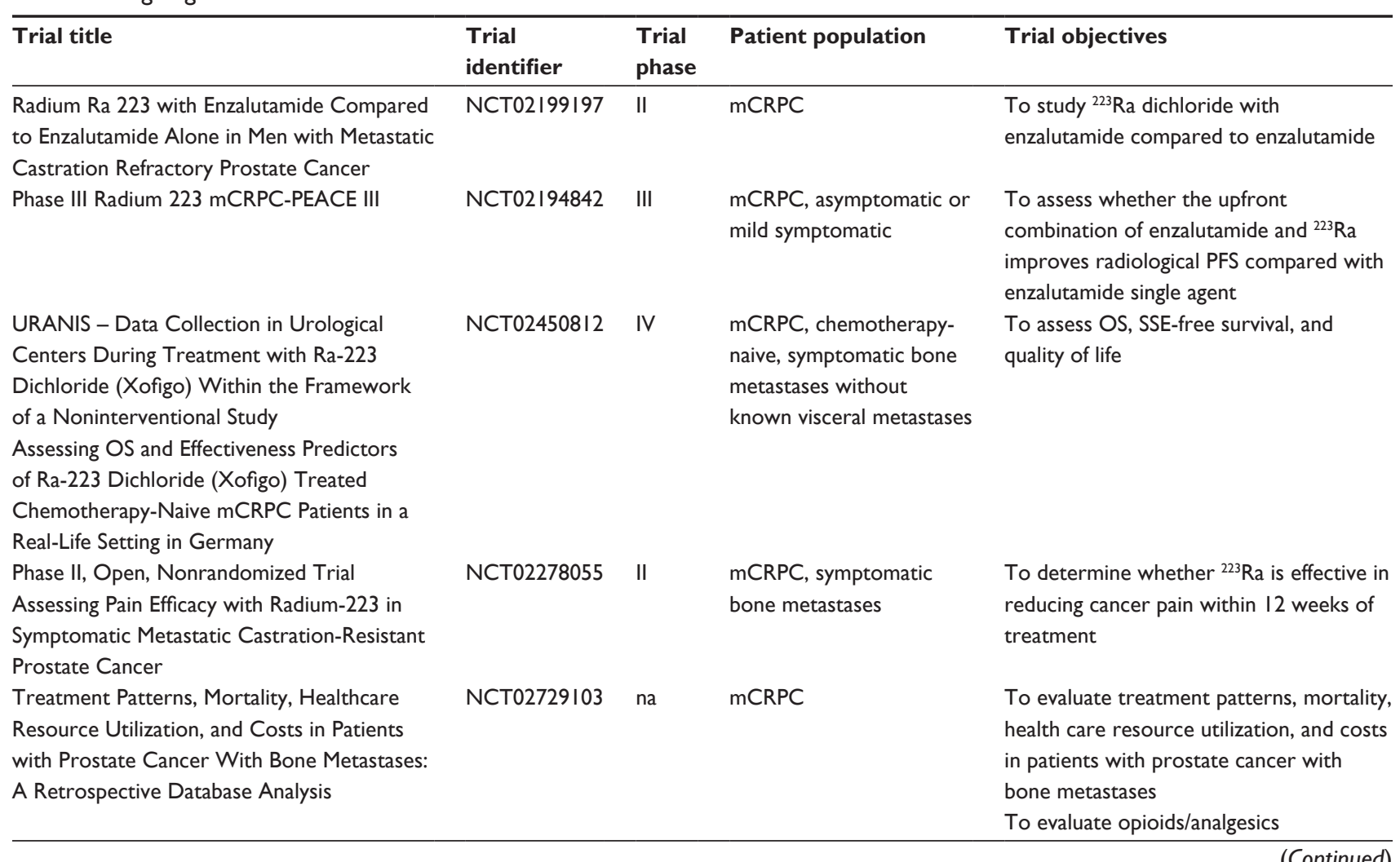


Table 3 (Continued)

\begin{tabular}{|c|c|c|c|c|}
\hline Trial title & $\begin{array}{l}\text { Trial } \\
\text { identifier }\end{array}$ & $\begin{array}{l}\text { Trial } \\
\text { phase }\end{array}$ & Patient population & Trial objectives \\
\hline $\begin{array}{l}\text { Drug Use Investigation of Xofigo, Castration- } \\
\text { Resistant Prostate Cancer with Bone } \\
\text { Metastases }\end{array}$ & NCT02803437 & IV & $\mathrm{mCRPC}$ & $\begin{array}{l}\text { To confirm the clinical usefulness, } \\
\text { especially the safety profile, of a drug in } \\
\text { the routine clinical practice }\end{array}$ \\
\hline $\begin{array}{l}\text { Observational Study for the Evaluation of } \\
\text { Long-term Safety of Radium- } 223 \text { Used for the } \\
\text { Treatment of Metastatic Castration-Resistant } \\
\text { Prostate Cancer (REASSURE) }\end{array}$ & NCT02I4I438 & IV & $\mathrm{mCRPC}$ & $\begin{array}{l}\text { To evaluate the short- and long-term } \\
\text { safety profile of }{ }^{223} \mathrm{Ra} \text { and to assess the } \\
\text { incidence of developing second primary } \\
\text { malignancies among patients with prostate } \\
\text { cancer who received }{ }^{223} \mathrm{Ra} \text { in routine } \\
\text { clinical practice settings }\end{array}$ \\
\hline $\begin{array}{l}\text { Phase II Open-Label Study to Evaluate the } \\
\text { Efficacy and Safety of Radium in Combination } \\
\text { with External Beam Radiotherapy (EBRT) vs }\end{array}$ & NCT02484339 & II & $\mathrm{mCRPC}$ & $\begin{array}{l}\text { To evaluate the efficacy and safety of }{ }^{223} \mathrm{Ra} \\
\text { dichloride in combination with EBRT vs } \\
\text { EBRT alone }\end{array}$ \\
\hline
\end{tabular}

EBRT Alone in the Treatment of Castration-

Resistant Prostate Carcinoma with Limited

Bone Metastases

uPAR PET/CT in Radium-223-Dichloride

Treatment of Patients with Metastatic

Castration-Resistant Prostate Cancer

Pain Evaluation in Radium-223-Treated

NCT02398526 IV mCRPC

Castration-Resistant Prostate Cancer Patients

NCT02964988 II MCRPC

with Bone Metastases (PARABO)

Prostate Cancer Intensive, Non-Cross

Reactive Therapy (PRINT) for Castration-

Resistant Prostate Cancer (CRPC)
Androgen Deprivation Therapy \pm Radium-

223 Dichloride in Metastatic Prostate Cancer with Bone Metastases

Studies of Prognostic Factors in CastrationResistant PROState Cancer Treated with Radium-223 (PRORADIUM)

A Phase III Randomized, Double-blind,

Placebo-Controlled Trial of Radium-223

Dichloride in Combination with Abiraterone

Acetate and Prednisone/Prednisolone

in the Treatment of Asymptomatic or

Mildly Symptomatic Chemotherapy-

Naive Subjects with Bone Predominant

Metastatic Castration-Resistant Prostate

Cancer (CRPC)

A Phase II Study of Radium-223 in

Combination with Enzalutamide in

Progressive Metastatic Castrate-Resistant

Prostate Cancer
NCT02582749 II Metastatic prostate cancer

$\begin{array}{lll}\text { NCT02925702 } & \text { IV } & \text { mCRPC } \\ \text { NCT02043678 III } & \text { mCRPC }\end{array}$

NCT02225704 II mCRPC
To investigate 68Ga-NOTA-AEI05 positron emission tomography/computed tomography for response evaluation of ${ }^{223}$ Ra therapy in $\mathrm{mCRPC}$

To assess pain- and bone pain-related quality of life in patients with $\mathrm{mCRPC}$ who received ${ }^{223} \mathrm{Ra}$ in a real-life nuclear medicine practice setting

To determine the clinical benefits of using a rapidly cycling, non-crossreactive regimen of US Food and Drug Administration-approved prostate cancer therapeutic agents

To explore the efficacy of rapidly cycling non-cross-reactive therapies for the treatment of patients with newly diagnosed $m C R P C$

To evaluate the safety and efficacy of androgen-deprivation therapy $\pm{ }^{223} \mathrm{Ra}$ dichloride in $\mathrm{mCRPC}$

To compare the good and bad effects of adding ${ }^{223} \mathrm{Ra}$ dichloride

To study prognostic factors in patients with $\mathrm{mCRPC}$ treated with ${ }^{223} \mathrm{Ra}$

To determine whether the addition of ${ }^{223} \mathrm{Ra}$ dichloride to standard treatment can prolong life and delay events specific to prostate cancer that has spread to the bone, such as painful fractures or bone pain that needs to be treated with an $X$-ray machine

To determine ${ }^{223}$ Ra safety and tolerability when administered in combination with enzalutamide in progressive $\mathrm{mCRPC}$

Abbreviations: EBRT, external beam radiotherapy; mCRPC, metastatic castration-resistant prostate cancer; na, not available; OS, overall survival; ${ }^{233}$ a, radium-223; PFS, progression-free survival; SSE, symptomatic skeletal event. 
patients with CRPC with bone metastases, alone or in combination with NHT, chemotherapy, or radiation therapy.

\section{Use in different countries}

Since its clinical approval in $2013,>27,000$ patients have received Xofigo ${ }^{\circledR}$ worldwide, among whom 12,000 were in Europe. It is currently prescribed and reimbursed in 23 European countries. More than 3,600 patients have been treated with Xofigo in Germany since 2013. If we only consider the prescriptions for 2016, 4,500 patients received Xofigo in the USA, 988 patients in England, 500 patients in Canada, 456 patients in Italy, 356 patients in the Netherlands, and 327 patients in Spain.

\section{Conclusion}

${ }^{223} \mathrm{Ra}$ has an original activity, and is the first drug in its class to have demonstrated a significant impact on OS in patients with mCRPC. Therefore, it has enriched the panel of therapeutic options for this disease, together with new-generation hormonal treatments and chemotherapy. Thanks to its relatively good toxicity profile, it could become the best option for a minority of patients with only bone metastases and who are unfit for docetaxel. Unfortunately, this drug is not reimbursed in all western countries. More clinical-economic analyses are needed to confirm the positioning of this novel drug in mCRPC therapeutic armamentarium.

\section{Acknowledgments}

This work has been facilitated by the Intergroupe Coopérateur Francophone de Recherche en Onco-urologie (ICFuro). This consortium brings together cooperating groups, scientific associations, and researchers working on clinical, basic, and translational research in urologic oncology in France and French-speaking countries. ICFuro objective is to promote all aspects of urologic oncology research and to allow the emergence of interdisciplinary, large-scale research programs.

The authors would like to thank ICFuro and specifically the "radium 223 - CPRC" French working group experts for bibliography reviewing and clinical data appraisal: oncologists (P Beuzeboc, Paris - N Houédé, Nîmes I Krakowski, Bordeaux - C Thibault, Paris); urologists (JL Descotes, Grenoble - X Rebillard, Montpellier, M Roumiguie, Toulouse, F Rozet, Paris); nuclear physicians (F Cachin, Clermont-Ferrand - F Courbon, Toulouse E Deshayes, Montpellier - D Huglo, Lille - JP Vuillez, Grenoble); radiotherapist (C Hennequin, Paris); geriatrician (V Fossey-Diaz, Paris); pharmacist (F Corréard, Marseille); and ICFuro methodologist (D Kassab-Chahmi, Paris).

\section{Disclosure}

The authors report no conflicts of interest in this work.

\section{References}

1. Wong MC, Goggins WB, Wang HH, et al. Global incidence and mortality for prostate cancer: analysis of temporal patterns and trends in 36 countries. Eur Urol. 2016;70(5):862-874.

2. Hoskin P, Sartor O, O'Sullivan JM, et al. Efficacy and safety of radium223 dichloride in patients with castration-resistant prostate cancer and symptomatic bone metastases, with or without previous docetaxel use: a prespecified subgroup analysis from the randomised, double-blind, phase 3 ALSYMPCA trial. Lancet Oncol. 2014;15(12):1397-1406.

3. Tannock IF, de Wit R, Berry WR, et al. Docetaxel plus prednisone or mitoxantrone plus prednisone for advanced prostate cancer. $N$ Engl J Med. 2004;351(15):1502-1512.

4. Berthold DR, Pond GR, Soban F, de Wit R, Eisenberger M, Tannock IF. Docetaxel plus prednisone or mitoxantrone plus prednisone for advanced prostate cancer: updated survival in the TAX 327 study. J Clin Oncol. 2008;26(2):242-245.

5. de Bono JS, Oudard S, Ozguroglu M, et al. Prednisone plus cabazitaxel or mitoxantrone for metastatic castration-resistant prostate cancer progressing after docetaxel treatment: a randomised open-label trial. Lancet. 2010;376(9747):1147-1154.

6. Kantoff P, Higano C, Shore N, et al; IMPACT Study Investigators. Sipuleucel-T immunotherapy for castration-resistant prostate cancer. N Engl J Med. 2010;363(5):411-422.

7. Fizazi K, Scher HI, Molina A, et al. Abiraterone acetate for treatment of metastatic castration-resistant prostate cancer: final overall survival analysis of the COU-AA-301 randomised, double-blind, placebocontrolled phase 3 study. Lancet Oncol. 2012;13(10):983-992.

8. Ryan CJ, Smith MR, Fizazi K, et al. Abiraterone acetate plus prednisone vs placebo plus prednisone in chemotherapy-naive men with metastatic castration-resistant prostate cancer (COU-AA-302): final overall survival analysis of a randomised, double-blind, placebo-controlled phase 3 study. Lancet Oncol. 2015;16(2):152-160.

9. Beer TM, Armstrong AJ, Rathkopf DE, et al. Enzalutamide in metastatic prostate cancer before chemotherapy. $N$ Engl J Med. 2014;371(5): 424-433.

10. Scher HI, Fizazi K, Saad F, et al. Increased survival with enzalutamide in prostate cancer after chemotherapy. $N$ Engl J Med. 2012;367(13): 1187-1197.

11. Esch L, Schulz WA, Albers P. Sequential treatment with taxanes and novel anti-androgenic compounds in castration-resistant prostate cancer. Oncol Res Treat. 2014;37(9):492-498.

12. Sonpavde G, Bhor M, Hennessy D, et al. Sequencing of Cabazitaxel and abiraterone acetate after docetaxel in metastatic castration-resistant prostate cancer: treatment patterns and clinical outcomes in multicenter community-based US oncology practices. Clin Genitourin Cancer. 2015; 13(4):309-318.

13. Lee KS, Kim HJ, Li QL, et al. Runx2 is a common target of transforming growth factor $\beta 1$ and bone morphogenetic protein 2, and cooperation between Runx2 and Smad5 induces osteoblast-specific gene expression in the pluripotent mesenchymal precursor cell line $\mathrm{C} 2 \mathrm{C} 12$. Mol Cell Biol. 2000;20(23):8783-8792.

14. Kim HJ, Kim JH, Bae SC, Choi JY, Kim HJ, Ryoo HM. The protein kinase $\mathrm{C}$ pathway plays a central role in the fibroblast growth factorstimulated expression and transactivation activity of Runx2. J Biol Chem. 2003;278(1):319-326.

15. Chaffer CL, Weinberg RA. A perspective on cancer cell metastasis. Science. 2011;331(6024):1559-1564.

16. Ibrahim T, Flamini E, Mercatali L, Sacanna E, Serra P, Amadori D. Pathogenesis of osteoblastic bone metastases from prostate cancer. Cancer. 2010;116(6):1406-1418.

17. Morris EV, Edwards CM. The role of bone marrow adipocytes in bone metastasis. J Bone Oncol. 2016;5(3):121-123. 
18. Logothetis CJ, Lin SH. Osteoblasts in prostate cancer metastasis to bone. Nat Rev Cancer. 2005;5(1):21-28.

19. Florimonte L, Dellavedova L, Maffioli LS. Radium-223 dichloride in clinical practice: a review. Eur J Nucl Med Mol Imaging. 2016;43(10): 1896-1909.

20. Henriksen G, Breistøl K, Bruland OS, Fodstad O, Larsen RH. Significant antitumor effect from bone-seeking, a-particle-emitting 223Ra demonstrated in an experimental skeletal metastases model. Cancer Res. 2002;62:3120-3125.

21. Henriksen G, Hoff P, Alstad J, Larsen RH. 223Ra for endoradiotherapeutic applications prepared from an immobilized 227Ac/227Th source. Radiochim Acta. 2001;89:661-666.

22. Henriksen G, Fisher DR, Roeske JC, Bruland OS, Larsen RH. Targeting of osseous sites with a-emitting 223Ra: comparison with the b-emitter 89Sr in mice. J Nucl Med. 2003;44(2):252-259.

23. Bruland OS, Nilsson S, Fisher DR, Larsen RH. High-linear energy transfer irradiation targeted to skeletal metastases by the alpha-emitter 223Ra: adjuvant or alternative to conventional modalities? Clin Cancer Res. 2006;12(20 Pt 2):6250s-6257s.

24. Lassmann M, Nosske D. Dosimetry of 223Ra-chloride: dose to normal organs and tissues. Eur J Nucl Med Mol Imaging. 2013;40(2): 207-212.

25. Nilsson S, Larsen RH, Foss SD, et al. First clinical experience with $\alpha$-emitting radium-223 in the treatment of skeletal metastases. Clin Cancer Res. 2005;11(12):4451-4459.

26. Carrasquillo JA, O'Donoghue JA, Pandit-Taskar N, et al. Phase I pharmacokinetic and biodistribution study with escalating doses of 223Ra-dichloride in men with castration-resistant metastatic prostate cancer. Eur J Nucl Med Mol Imaging. 2013;40:1384-1393.

27. Ritter MA, Cleaver JE, Tobias CA. High-LET radiations induce a large proportion of non-rejoining DNA breaks. Nature. 1977;266(5603): 653-655.

28. Parker CC, Pascoe S, Chodacki A, et al. A randomized, double-blind, dose-finding, multicenter, phase 2 study of radium chloride ( $R a 223$ ) in patients with bone metastases and castration-resistant prostate cancer. Eur Urol. 2013;63(2):189-197.

29. Parker C, Nilsson S, Heinrich D, et al. Alpha emitter radium-223 and survival in metastatic prostate cancer. N Engl J Med. 2013;369(3): 213-223.
30. Vogelzang HJ, Coleman RE, Michalski JM, et al. Hematologic safety of radium-223 dichloride: baseline prognostic factors associated with myelosuppression in the ALSYMPCA trial. Clin Genitourin Cancer. 2017;15(1):42-52.

31. Nilsson S, Cislo P, Sartor O, et al. Patient-reported quality of life analysis of radium-223 dichloride from the phase 3 ALSYMPCA study. Ann Oncol. 2016;27(5):868-874.

32. Saad F, Carles J, Gillessen S, et al. Radium-223 and concomitant therapies in patients with metastatic castration-resistant prostate cancer: an international, early access, open-label, single-arm phase $3 \mathrm{~b}$ trial. Lancet Oncol. 2016;17(9):1306-1316.

33. Alva A, Nordquist L, Daignault S, et al. Clinical correlates of benefit from radium-223 therapy in metastatic castration resistant prostate cancer. Prostate. 2017;77(5):479-488.

34. Hague C, Logue JP. Clinical experience with radium-223 in the treatment of patients with advanced castrate resistant prostate cancer and symptomatic bone metastases. Ther Adv Urol. 2016;8(3):175-180.

35. Nilsson S, Strang P, Aksnes AK, et al. A randomized, dose-response, multicenter phase II study of radium-223 chloride for the palliation of painful bone metastases in patients with castration-resistant prostate cancer. Eur J Cancer. 2012;48(5):678-686.

36. Sartor O, Coleman R, Nilsson S, et al. Effect of radium-223 dichloride on symptomatic skeletal events in patients with castration-resistant prostate cancer and bone metastases: results from a phase 3, doubleblind, randomised trial. Lancet Oncol. 2014;15(7):738-746.

37. Dauer LT, Williamson MJ, Humm J, et al. Radiation safety considerations for the use of (2)(2)(3) RaCl(2) DE in men with castrationresistant prostate cancer. Health Phys. 2014;106(4):494-504.

38. Barre E, Nguyen ML, Bruel D, et al. [Extravasation of radiopharmaceuticals: preventive measures and management recommended by SoFRa (Societe Francaise de Radiopharmacie)]. Ann Pharm Fr. 2013; 71(4):216-224. French.

39. Benjegerdes KE, Brown SC, Housewrigh CD. Focal cutaneous squamous cell carcinoma following radium-223 extravasation. Proc (Bayl Univ Med Cent). 2017;30(1):78-79.
Drug Design, Development and Therapy

\section{Publish your work in this journal}

Drug Design, Development and Therapy is an international, peerreviewed open-access journal that spans the spectrum of drug design and development through to clinical applications. Clinical outcomes, patient safety, and programs for the development and effective, safe, and sustained use of medicines are the features of the journal, which

\section{Dovepress}

has also been accepted for indexing on PubMed Central. The manuscript management system is completely online and includes a very quick and fair peer-review system, which is all easy to use. Visit http://www.dovepress.com/testimonials.php to read real quotes from published authors. 